Т. О. Перцева, I. С. Шпонька, О. О. Гудар'ян, О. О. Фастовець Державний заклад “Дніпропетровська медична академія Міністерства охорони здоров'я України"

\title{
ДОСВІД ОРГАНІЗАЦІЇ КОМПЛЕКСНОГО ПРАКТИЧНО- ОРІЄНТОВАНОГО ІСПИТУ ЗІ СПЕЦІАЛЬНОСТІ “СТОМАТОЛОГІЯ” ЗА ПРИНЦИПАМИ OSCE
}

\author{
T. O. Pertseva, I. S. Shponka, O. O. Hudarian, O. O. Fastovets \\ State Institution "Dnipropetrovsk Medical Academy of the Ministry of Health of Ukraine" \\ EXPERIENCE OF THE COMPLEX PRACTICAL ORIENTED \\ EXAMINATION ORGANIZATION FOR SPECIALTY “STOMATOLOGY” \\ ACCORDING TO THE PRINCIPLES OF THE OSCE
}

\begin{abstract}
Мета роботи - висвітлити значення впровадження принципів OSCE для забезпечення адекватного підходу до контролю рівня компетентностей під час комплексного практично-орієнтованого іспиту зі стоматології.

Основна частина. Впровадження комплексного практично-орієнтованого екзамену (OSCE) дозволяє здійснити перевірку готовності випускника на реальному об’єкті майбутньої професійної діяльності (людині) до виробничих функцій, які важко оцінити методом стандартизованого тестування.

Впровадження симуляційних технологій у навчальний процес ДЗ “ДМА” допомагає вирішенню проблеми недостатньої кількості тематичних пацієнтів. Симуляційне обладнання дозволяє відтворити елементи OSCE, та знизити варіативність оцінки осіб, що екзаменуються. Стандартизація клінічних ситуацій із застосуванням методу кейс-стаді забезпечує повну ідентичність завдань, які дають студентам під час атестації, а перевірка комунікативних навичок проводиться екзаменатором, який одночасно виконує функцію імітатора. Демонстрацію рівня засвоєння основних умінь та практичних навичок зі стоматологічних спеціальностей студент здійснює на фантомах-тренажерах. Оцінювання студентів проводиться за загальноприйнятою методикою.

Висновки. Застосування принципів об’єктивного структурованого клінічного екзамену (OSCE) та елементів симуляційного навчання забезпечує високу ефективність контролю засвоєння “компетентностей” майбутнього фахівця та рівня оволодіння практичними навичками зі стоматологічних дисциплін. Залучення імітаторів у сукупності із застосуванням фантомів-тренажерів дозволяє удосконалити комплексний практично-орієнтований іспит зі стоматології.
\end{abstract}

Ключові слова: стоматологія; об’єктивний структурований клінічний екзамен; симуляційне навчання; практичні навички.

The aim of the work - to highlight the importance of implementing the OSCE principles to ensure an adequate approach to controlling the level of competences in an integrated practical-oriented exam for speciality "Stomatology".

The main body. The implementation of an objective structured clinical examination (OSCE) allows you to check the level of preparation of a graduate student to a future professional activity (work with patient) that is difficult to assess by standardized testing.

The usage of simulation technologies in the educational process of the SI "DMA" helps to solve the problem of insufficient number of thematic patients. The simulation equipment allows you to recreate the OSCE elements, and reduce the variability in the assessment of examiners. The standardization of clinical situations using the case-practice method ensures the full identity of the tasks that are provided to students during the certification process, and the testing of communicative skills is carried out by an examiner, who simultaneously performs the function of the simulator. Demonstration by a student of the level of mastering of basic skills and practical skills from dental specialties is carried out on phantom-simulators. Assessment of students is carried out according to the generally accepted methodology.

Conclusions. The application of the principles of an objective structured clinical examination (OSCE) and elements of simulation training provides a high level of effectiveness in monitoring the mastery of the "competence" of a future specialist and the level of mastery of practical skills in Stomatology disciplines. Involvement of simulators in combination with the use of phantom simulators allows to improve the complex practical-oriented examination in stomatology.

Key words: stomatology (dentistry); objective structured clinical examination; simulation training; practical skills.

(c) Т. О. Перцева, І. С. Шпонька, О. О. Гудар’ян, О. О. Фастовець 
Вступ. Сучасні тенденції розвитку медичної освіти вимагають заміни “інформаційного” підходу освітніх програм на “компетентнісний”, який передбачає формування у студента готовності використовувати отримані знання, уміння й навички для вирішення практичних завдань у процесі професійної діяльності [1]. Відповідно до цього, згідно $з$ новою програмою навчання фахівців другого (магістерського) рівня вищої освіти за спеціальністю 221 “Стоматологія” освітньої кваліфікації “Магістр стоматології”, професійної кваліфікації “Лікар-стоматолог”, особлива увага приділяється рівню компетенцій, як загальних, так і спеціальних (фахових) [2]. Відповідно до матриці, компетенції потребують певних знань, умінь, комунікацій, а також автономії і відповідальності.

Зміна освітніх пріоритетів потребує інновацій не тільки у навчальному процесі, але й в засобах контролю якості його проведення [3]. Згідно з нашим досвідом, отриманим під час атестації випускників-стоматологів у 2016/2017 навчальному році, забезпечити адекватний підхід, орієнтований на перевірку рівня компетентностей під час комплексного практично-орієнтованого іспиту зі стоматології, дозволяє впровадження принципів OSCE (objective structured clinical examination), що передбачає використання стандартизованих клінічних ситуацій із залученням акторів-імітаторів і застосуванням фантомів-тренажерів [4].

Мета роботи - висвітлити значення впровадження принципів OSCE для забезпечення адекватного підходу до контролю рівня компетентностей під час комплексного практично-орієнтованого іспиту зі стоматології.

Основна частина. Насамперед, зазначимо, що Д3 “ДМА” одним із перших в Україні у 2002 році запровадив комплексний практично-орієнтований екзамен для проведення підсумкової атестації студентів-випускників зі спеціальності “Стоматологія”. Особливістю такої форми екзаменування є перевірка готовності випускника здійснювати на реальному об'єкті майбутньої професійної діяльності (людині) виробничі функції, які неможливо оцінити методом стандартизованого тестування.

Як показав досвід, попри всі переваги, головною проблемою зазначеної форми атестації є брак тематичних хворих, що забезпечують показовість та багатопрофільність процедури оцінки вмінь та практичних навичок студентів. Звичайно ті пацієнти, на яких демонструвався діагностичний і лікувальний процес, були однотипними, та мали найбільш поширене захворювання - карієс зубів. Таким чином, студент мав можливість продемонструвати практичні навички переважно з терапевтичної стоматології, тоді як оцінити вміння з решти спеціальностей було практично неможливо. Проблему вдавалось лише частково вирішувати шляхом застосування різного роду моделей та муляжів. Одночасно при діагностуванні більш складних нозологій, що потребували трудомістких стоматологічних втручань, затрачався більший час, що значно порушувало регламент іспиту, тому що студент не міг припинити лікувальні заходи, після демонстрації потрібної маніпуляції. Певна “нервозність” самих студентів та їх хворих також не сприяла ні якісному лікуванню, ні об’єктивізації результатів іспиту.

Впровадження симуляційних технологій у навчальний процес ДЗ “ДМА” допомогло вирішенню проблеми, що виникла. Так, у 2013 році з'явився перший клас із 10 фантомів-тренажерів, які повністю імітували зубощелепний апарат людини, та дозволили проведення маніпуляцій з усіх розділів стоматології. Натепер академією придбано 70 фантомів-тренажерів та 36 фантомів для відпрацювання практичних навичок, пов'язаних із місцевим знеболенням, які були розташовані на кафедрах стоматологічного профілю.

Поява симуляційного обладнання дала змогу відтворити під час державної атестації студентіввипускників елементи OSCE, i, в першу чергу, його головний принцип - зниження варіативності оцінки осіб, що екзаменуються. В нашому випадку його реалізація передбачала стандартизацію клінічних ситуацій, що забезпечувала повну ідентичність завдань, які надаються студентам під час атестації.

Наступний обов'язковий принцип OSCE, який вдалося відтворити, - це перевірка комунікативних навичок за рахунок присутності імітатора, який одночасно був екзаменатором.

Нарешті, змінні блоки різної комплектації на фантомах-тренажерах дозволили імітувати будьякі клінічні ситуації та демонструвати практичні навички з усіх розділів стоматології, зокрема ті, що включені до галузевих стандартів вищої освіти ОПП та ОКХ. При цьому розбивка кожної практичної навички на низку маніпуляцій дозволила при економії часу продемонструвати уміння з кожної стоматологічної спеціальності.

Отже, згідно з затвердженим регламентом, комплексний практично-орієнтований іспит складався 
3 двох частин, перша з яких - робота зі стандартизованим, спеціально підготовленим, пацієнтомімітатором, здатним чітко та послідовно доповісти скарги, розповісти про розвиток захворювання, надати інформацію про загальний стан, зімітувати больовий синдром тощо.

При цьому кожний стандартизований пацієнт імітував захворювання згідно з номером білета, який отримав студент. Розподіл захворювань за дисциплінами та білетами був затверджений на засіданнях кафедр, узгоджений з предметною комісією “Стоматологія” та затверджений на засіданні ЦМК Д3 “ДМА”. Логістика екзамену вимагала також створення так званих технологічних карт, у яких повністю описувались скарги, які повинен надавати імітатор, тактика його поведінки, зазначались можливі запитання з боку студента та варіанти відповідей на них. Більш того, під час іспиту застосований метод кейс-стаді, тобто доповнення імітації ситуації на фантомі не тільки скаргами пацієнтаімітатора, але й результатами додаткових методів дослідження (рентгенографічних, лабораторних, функціональних тощо). На підставі результатів основних методів обстеження студенту пропонувалось сформулювати 2-3 попередніх діагнози, а потім обрати остаточний із застосуванням даних додаткового обстеження з подальшим складанням плану лікування. Подібним чином вдавалось відтворити весь лікувально-діагностичний процес та відслідкувати рівень компетентності студента.

У свою чергу, друга частина екзамену включала демонстрацію студентом на фантомах-тренажерах рівня засвоєння основних умінь та практичних навичок зі стоматологічних спеціальностей, перелік та кількість яких були визначені згідно з освітньокваліфікаційною характеристикою спеціаліста. Максимальна візуалізація виконання поставленого практичного завдання дозволила об’єктивну оцінку екзаменатором.

\section{Список літератури}

1. Про вищу освіту : Закон України від 01.07.2014 року № 1556-VII. - Режим доступу : http://zakon2.rada.gov.ua/ laws/show/1556-18.

2. Стандарт вищої освіти України (Другий (магістерський)) на звання магістра з галузі знань 22 “Охорона здоров’я”, спеціальності 221 “Стоматологія”. - http:// umsa.edu.ua/pidrozdilhome/navmetlab/pdf/proekt_2017_ galuz_standart_osv_stom221.pdf.
Виконання типових задач щодо діяльності та умінь, які демонструвались під час першої частини іспиту, оцінювалось балами “1”, “0,5” та “0” (виконано, виконано не повністю, не виконано). Тоді як рівень розв’ язання ситуаційних задач, основних умінь і навичок, які перевірялись під час другої частини іспиту, визначали за двобальною системою “1” та “0”, відповідно, виконано або ні. Підсумковий результат із чотирьох стоматологічних дисциплін за клінічний практично-орієнтований іспит підраховували як середнє арифметичне всіх балів, помножене на коефіцієнт 200. Критерії встановлення традиційної оцінки з дисципліни за вимогами Єдиної державної бази освіти України (ЄДБО) були наступні: 200-170 балів - “відмінно”, 169140 балів - “добре”, 139-101 бал - “задовільно”, 100 і менше балів - “незадовільно”.

Висновки. Згідно з досвідом проведення атестації студентів-випускників стоматологічного факультету ДЗ “ДМА”, застосування принципів об’ єктивного структурованого клінічного екзамену (OSCE) та елементів симуляційного навчання забезпечує високу ефективність контролю засвоєння “компетентностей” майбутнього фахівця i рівня оволодіння практичними навичками зі стоматологічних дисциплін. Залучення імітаторів у сукупності із застосуванням фантомів-тренажерів дозволяє удосконалити комплексний практичноорієнтований іспит зі стоматології такими елементами OSCE, як стандартизація пацієнта, імітація потрібної нозології, перевірка комунікативних навичок. Насамкінець зазначимо, що значна ефективність симуляційних технологій у навчальному процесі сприяла тому, що у грудні 2017 року рішенням Вченої ради ДЗ “ДМА” було прийнято рішення про створення міжкафедрального симуляційного центру для підготовки та підсумкової атестації студентів-стоматологів.

3. Удосконалення якості підготовки лікарів у сучасних умовах : матеріали наук.-практ. конф. з міжнар. участю. Полтава : ВДНЗУ “УМСА”, 2016. - 266 с.

4. Муравьев К. А. Симуляционное обучение в медицинском образовании - переломный момент / К. А. Муравьев, А. Б. Ходжаян, С. В. Рой // Фундаментальные исследования. - 2011. - № 10. - С. 534-537. 


\section{References}

1. Zakon Ukrainy vid 01.07.2014 № 1556-VII Pro vyshchu osvitu [Higher Education Act of Ukraine No. 1556VII of July 1, 2014]. - Retrieved from: http://zakon2.rada. gov.ua/laws/show/1556-18 [in Ukrainian].

2. Standart vyshchoi osvity Ukrainy (Druhyi (mahisterskyi)) na zvannia mahistra z haluzi znan 22 Okhorona zdorovia, spetsialnosti 221 Stomatolohiia. - Retrieved from: http:// umsa.edu.ua/pidrozdilhome/navmetlab/pdf/proekt_2017_ galuz_standart_osv_stom221.pdf ] [in Ukrainian].

3. Udoskonalennia yakosti pidhotovky likariv u suchasnykh umovakh [Improvement of doctors' training quality in modern conditions]. Materialy nauk. prakt. konf. z mizhnar. uchastiu - Materials of Scientific-practical Conference with International Participation. Poltava: VDNZU "UMSA" [in Ukrainian].

4. Muravyev, K.A., Khodzhayan, A.B., \& Roy, S.V. (2011). Symulyatsyonnoe obuchenie v meditsinskom obrazovanii - perelomnyy moment Simultaneous studying in medical education - a crucial moment]. Fundamentalnye issledovaniya - Fundamental Researches, 10, 534-537 [in Ukrainian]. 